\title{
Efficiency of the Self-Assessment System of Taxation in Nigeria
} Jacob Moses Eseneyen ${ }^{1 *}$, Uket Ewa ${ }^{2}$

${ }^{1}$ Budget and Expenditure Control, Bursary Department, University of Uyo, Uyo, Nigeria

${ }^{2}$ Department of Accountancy, Cross River University of Technology, Calabar, 540000, Nigeria

DOI: $10.36347 /$ sjebm.2020.v07i09.001

| Received: 27.07.2020 | Accepted: 03.08.2020 | Published: 02.09.2020

*Corresponding author: Jacob Moses Eseneyen

Abstract

Original Research Article

The major objective of this study is to determine the impact of the self-assessment system of taxation on tax revenue in Nigeria. It was prompted by the major change and liberalisation in self-assessment system of tax administration in Nigeria in 2011. The study employed ex post facto experimental design to evaluate the difference in tax revenue before and after SAS implementation. It covered a period of 16 years, 2003 to 2018, eight years each of pre and post implementation of the system in Nigeria. Secondary data were obtained from Central Bank of Nigeria statistical bulletin and from the website of Federal Inland Revenue Service. Three research questions and two hypotheses were formulated to guide the study. Tax/GDP ratio and actual/target tax collection ratio were used to measure the efficiency of this system of taxation. The results of the analysis indicate a post- SAS (2011 to 2018) tax/GDP mean value of $5.07 \%$ lower than pre-SAS (2003 to 2010) tax to GDP ratio of $6.23 \%$. Similar results were obtained using actual/target tax collection ratio. Further analysis, using paired sample t-test for pre and post SAS period tax/GDP ratio at $95 \%$ confidence level found this difference to be statistically insignificant, $\mathrm{t}(7)=1.819<1.895$ and the $\mathrm{p}$-value was 0.112 $>0.05$. It is therefore concluded that Self-Assessment System of taxation has a negative but insignificant effect on tax revenue in Nigeria. Since the efficiency of SAS has been well documented in several empirical studies in other countries, this study recommends a further review of the Self-Assessment Regulation 2011 to explore other means, in conjunction with the SAS, of improving efficiency of tax collection in Nigeria.

Keywords: Taxation, Self-assessment, Gross Domestic Product, Petroleum Profit Tax.

Copyright @ 2020: This is an open-access article distributed under the terms of the Creative Commons Attribution license which permits unrestricted use, distribution, and reproduction in any medium for non-commercial use (NonCommercial, or CC-BY-NC) provided the original author and source are credited.

\section{INTRODUCTION}

All over the world, taxes are a major source of raising revenue to finance public expenditure. Since the discovery of crude oil in Nigeria in 1958 , the product has become Nigeria's major revenue source. In the year 2018 oil revenue accounted for over $70 \%$ of the country's total revenue [10]. The situation has caused pundits to describe Nigeria as a mono product economy. The fears also exist that crude oil, being a wasting asset, would dry off or worse still that advancing technology, as in electric cars, would replace fossil fuel in the near future thereby shrinking revenue from oil. The need to enhance non-oil revenue and diversify the economy became pertinent. In order to improve revenue from taxes there has been consistent policy reforms over the years in Nigeria [16]. One of such reform is the self-assessment system (SAS) of tax administration and collection.

Traditionally, it has been the tax authorities that determine the tax liability of a taxpayer in line with extant tax laws and regulations. This approach is usually referred to as the Administrative Assessment
System (AAS). However, in order to encourage voluntary compliance and reduce administrative cost, many countries have enacted laws and amended regulations that allow the taxpayer to be more involved and play a leading role in the process leading to tax payments. This approach is referred to as the SelfAssessment System. The Self-Assessment System, which is driven by the need to improve tax compliance and reduce administrative costs, commenced in 1996 in Nigeria. As of that time, only companies with a turnover of 1 million and above were required to file self-assessment returns. However, in 2011, the process and procedures for self-assessment was significantly modified to include taxes of those under Personal Income Tax Act (PITA, 2011) and Companies' Income Tax Act (CITA). The new regulation (Self-Assessment Regulation, 2011) requires all taxpayers, irrespective of turnover or the legal nature of the taxable person to file self-assessment returns. Prior to commencement of SAS in Nigeria, taxpayers file their returns and await government assessment before they pay the assessed taxes. Under the Self-Aassessment Regulation, 2011, they are now required to determine their taxable 
income, compute their tax liabilities, pay the taxes in designated banks and file evidence of payment along with the tax returns. The returns must comply with the relevant laws and policy statements. Penalty mechanism applies if the tax authority found out that the taxpayer submits returns that are not compliant with the law and the self-assessment regulations. It is a "do it yourself" system whereby the taxpayer has to understand, interpret and apply the law to his own state of affairs.

Studies in Malaysia by Loo [11] and in Indonesia by Saad [21], have shown that the SelfAssessment System (SAS) encourages voluntary compliance since the taxpayer would more likely comply with a tax liability which he imposes on himself. Increased compliance has thus led to increased tax revenue in countries such as Australia, Japan and Kenya and Ghana, where SAS had been implemented. In Ghana, for example, tax revenue as a percentage of GDP for the decade 2007 to 2016, averaged 16.3\%, which is considered very good for an African country.

Self-Assessment System is now considered as international best practice. This is evident from the recent steady movement away from administrative assessment to self-assessment system by many countries in the world [17]. Self-assessment for tax purpose is not a new idea. It was first implemented in Canada and the United States of America in the 1910s, followed by Japan in 1947 [11]. In the last 30 years though, the prevalence of self-assessment for the purpose of income tax has been extraordinary.

Above all, it is the desire of governments to improve revenue generation from income taxes, usually measured by Tax/Gross Domestic Product (GDP) ratio. The efficiency of the self-assessment can also be gauged by using the extent to which tax authorities such as the Federal Inland revenue Services (FIRS) is meeting its tax collection targets (actual/target tax ratio). It has now been nine years since the selfassessment system of taxation was significantly modified in Nigerian. Nine years down the line, it would be interesting to find out how this popular system of tax administration and collection has impacted on tax revenue in Nigeria. The major objective of this study, therefore is to investigate the impact of self-assessment system on tax revenue in Nigeria.

\section{OBJECTIVE OF THE STUDY}

The main objective of this study is to investigate the impact of self-assessment system on tax revenue in Nigeria. Specifically, the study seeks to:

- Determine revenue generated from tax before and after the implementation of SAS in Nigeria

- Analyse the difference between actual/target tax collection before and after the implementation of self-assessment in Nigeria.
- Evaluate the difference between tax/GDP ratio before and after the implementation of selfassessment in Nigeria.

\section{RESEARCH HYPOTHESES}

The hypotheses to be tested in this study are stated in the null form as follows:

Ho 1: There is no significant statistical difference in mean value of actual/target tax collection before and after the implementation of self-assessment in Nigeria

Ho 2: There is no significant statistical difference in mean value of tax/ GDP ratio before and after the implementation of selfassessment in Nigeria.

\section{LITERATURE \\ Conceptual literature \\ Issues in self-assessment system}

The Self-Assessment System simply assumes that that the taxpayer knows the tax law and is honest. Therefore, the information he provides in his tax returns is correct and should be relied on by the tax administrators. The challenge however, is that if any of these assumptions does not hold (which is most probable) then the tax liability which the taxpayer imposes on himself would be wrong which can impact tax revenue negatively. According to Wood et al. [22] two conditions are necessary for implementation of SAS. These conditions are referred to as primary and secondary functions. The primary function is the determination of a taxpayer's liability. This involves the ascertainment of income that is subject to tax, knowing and deducting the allowable expenses from it, knowing and applying tax reliefs and allowances, computing the chargeable income and applying the appropriate and applicable tax rates. The secondary function includes checking the correctness of the tax returns submitted by the taxpayer using various auditing techniques and imposing sanctions for non-compliance. Under SAS, the primary function, which is considered equally crucial, is reneged by the tax officials and the burden is shifted to the taxpayer who is more likely to lack the knowledge, the competence, skill and honesty required to assume the responsibility. This drawback of SAS is capable of having a negative effect on the efficiency of this popular system of taxation [17].

\section{Measures of Efficiency of a Tax System}

The efficiency of a tax system is seen when a country gets more revenue from taxes from year to year. The efficiency of the self-assessment system of the collection can be measured by - tax/GDP ratio and actual/target tax collection. These proxies for measuring efficiency are discussed in this section.

\section{Tax Revenue to GDP ratio}

One of the ways in which the efficiency of the tax system can be gauged is through the use of tax to gross domestic product (GDP) ratio. It offers a better 
measure of the rise and fall in tax revenue than simple numbers and also determines how well a nation's government directs its economic resources through taxation [7]. According to Anjaneyulu [2] the most important measure for improving tax to GDP ratio is ensuring the citizens pay their taxes. Ramprasad [20] identified tax evasion, lower tax rates, loopholes in tax law, narrow tax base as causes of low tax to GDP ratio in India. The objective of the self-assessment system in Nigeria was to improve voluntary compliance, reduce cost of tax collection and improve revenue from taxes. Kolade \& Ajogbor [9], observed a narrow tax base in Nigeria, years after implementation of SAS in Nigeria and stated that the situation places a huge burden on tax-paying citizens. Making reference to 2016 IMF report they stated that only 10 million out of a possible 77 million people in Nigeria registered for tax purpose.

\section{Actual /Target Tax Revenue in Nigeria}

The Federal Inland Revenue Act, 2007 grants

the Federal Inland Revenue Services (FIRS) the authority to collect all manner of taxes to generate revenue for government expenditure. Annually, the President and Commander in Chief of Nigeria gives a revenue target to the Service. The performance of the Chairman and Chief Executive Officer of the Service is usually based on the extent to which the Service meet the target. The President did not renew the appointment of the immediate past Chairman and Chief Executive Officer (2015-2019) of the Service, and failure to meet tax revenue target was fingered as a major reason. The tax revenue target for year 2020 is N8.5trillion which is achievable if the tax based is widened as implied by Kolade \& Ajogbor [9]. However, the current boss of FIRS has already expressed doubt regarding the ability of the Service to meet the "unusual and huge" target [18]. He has sought the assistance of the Lagos State Government in the area of sharing information with the Service to make generating the N8.5 trillion target possible since majority of multinational companies alleged to be evading taxes are resident in Lagos State. The ratio of actual/target tax collection has therefore become a crucial indicator for assessing the efficiency of a tax system such as SAS.

An applicable theory of what motivate the paying of taxes voluntarily is discussed in the next section.

\section{Attribution Theory}

This theory proposed by Kelly [8] can be used to explain what motivates the taxpayer to voluntary compliance resulting in improved tax revenue to GDP ratio. Attribution theory has to do with the way people explain why things happen. When things happen, one of two types of attributions (or explanation) can be made. Firstly, an external attribution can be made, or one can make an internal attribution. When the attribution is external, causality is assigned to an outside agent or force, for example, "I pay taxes because I am aware of fines and penalties, and I know that I will be sanctioned if I fail to comply". That is an external attribution when something outside (the fines and penalties imposed for non-compliance) motivates the event (the paying of taxes). By contrast, internal attribution assign causality within the person (or the taxpayer). For example, "I pay my taxes because it is one of my responsibilities, as a good citizen, to do so". Here the taxpayer is fully aware of the importance of tax revenue to a modern society and values the responsibilities of a good citizen - the motivation to pay is from within. It is the kind of motivation the self-assessment seeks to achieve, by urging taxpayers to determine their tax liability by themselves. The trust reposed by tax authorities on the taxpayer should hopefully motivate voluntary compliance.

According to this theory, external attribution can undermine an existing (good) habit. For example, a taxpayer can lose a positive attitude towards tax compliance if he changes his pattern of attribution. External attribution can only be effective if the receiver believes that he deserves the external factor for internal reasons [4]. The external attribution would work well if for instance, the taxpayer believed that he deserved the penalty because he did a bad thing. If, however, the taxpayer believed that he did nothing to deserve the external factor; then the external agent (fines, penalties) is not likely to cause any enduring internal change for a better attitude.

\section{EMPIRICAL LITERATURE}

According to Eseneyen [5], a significant positive relationship exists between taxpayers' tax knowledge and their attitude towards tax compliance. The study also found out that the Nigerian taxpayer under Personal Income tax Act as amended lacked the requisite knowledge to handle the burden of selfassessment. Although the law allows professional such as chartered accountants to file self-assessment returns on behalf of clients, he argued that most operators of Micro, Small and Medium Enterprise lack the requisite fund to pay for such professional services. This lack of required tax knowledge heightened the probability of incorrect assessment leading to unintentional noncompliance and poor revenue from taxes among this category of taxpayers. Earlier studies on selfassessment that reached similar conclusion include the study of Nurlis [15], who acknowledged the complexity of the tax laws in United Kingdom and opined that it would take an estimated 13 years of learning period to understand and apply them [14], and admitted that tax rules are complex because the level of abstraction is high.

Masud, A et al., [13] examined the difference in tax compliance and complexity before and after the implementation of SAS in Nigeria. They used data obtained from paying taxes report for the period 2008 2014 from Price Waterhouse Coopers (PWC) and 
employed paired sample t-test for the analysis of the data obtained. They found a "slightly higher" but statistically insignificant post self-assessment system tax compliance. They also found out that tax laws were slightly less complex but statistically insignificant under SAS. A study conducted by Appah \& Ogbonna [1] investigated the association between self-assessment compliant rate and revenue generation in Nigeria. Data were obtained through a structured questionnaire with three sections and 39 items with an average reliability score of 0.71 . Analyses of the data revealed a strong association between self-assessment compliant rate and revenue generation. They recommend increased education of taxpayers by federal Inland revenue Service to further improve the self-assessment compliant rate.

Eluro [3] investigated the determinants of compliance under the self-assessment system in Nigeria. Using structured questionnaire with 24 items, primary data were obtained from taxpayers in Delta North senatorial Zone in Delta State Nigeria. Analysis of data was done using both inferential and descriptive statistics technique. The study found out that tax complexity is a major cause of tax non-compliance under the self-assessment system in Nigeria.

\section{METHODOLOGY}

The objective of the study is to examine the effect of the implementation of self-assessment system of tax collection and administration on revenue from taxes in Nigeria. Secondary data was obtained from the Central Bank of Nigeria Statistical bulletin and from Publications of the Federal Inland Revenue Service from 2003 to 2018. Time series ex post facto experimental design was adopted for this study. Tax revenue performance indicators (tax/GDP ratio; actual/target tax revenue ratio) were computed from the secondary data obtained from CBN Statistical bulletin and FIRS publications. The data obtained were analysed using descriptive techniques and paired sample t- test as analyses tool. The pre-SAS implementation period of 2003 to 2010 was adopted and 2011 to 2018 as period for post implementation of SAS, that is, eight years each of pre and post implementation of SAS in Nigeria. Efficiency of the tax system is measured by tax to GDP ratio and the actual/target tax ratio for the years before and after implementation. The null hypotheses are accepted if there is no significant difference in mean between the pre and post implementation performance indicators and is rejected if there are statistically significant differences.

\section{Data Presentation, Analyses and Discussion}

The data obtained for this study are presented in tables and charts as shown in this section. Tables 1 and 2 show the pre-SAS and post-SAS implementation actual/target tax revenue and the percentage of the target that was achieved for the period 2003 to 2010; and 2011 to 2018 .

Table-1: Pre-SAS Actual and Target Tax Collection by FIRS (2003 to 2010)

\begin{tabular}{|l|l|l|l|}
\hline Year & Target Nbillion & Actual Nbillion & \% Achieved \\
\hline 2003 & 572.90 & 703.1 & 122.73 \\
\hline 2004 & 800.00 & $1,194.80$ & 149.35 \\
\hline 2005 & $1,304.40$ & $1,741.80$ & 133.53 \\
\hline 2006 & $3,054.10$ & $1,866.20$ & 61.10 \\
\hline 2007 & $1,753.30$ & $1,846.90$ & 105.34 \\
\hline 2008 & $2,274.40$ & $2,972.20$ & 130.68 \\
\hline 2009 & $1,909.00$ & $2,197.60$ & 115.12 \\
\hline 2010 & $2,557.30$ & $2,839.30$ & 111.03 \\
\hline Mean & & & $\mathbf{1 1 6 . 1 1}$ \\
\hline
\end{tabular}

Source: FIRS Publications, 2020

Table-2: Post-SAS Target and Actual Tax Collection by FIRS (2011 to 2018)

\begin{tabular}{|l|l|l|l|}
\hline Year & Target Nbillion & Actual Nbillion & \% Achieved \\
\hline 2011 & $3,639.10$ & $4,628.50$ & 127.19 \\
\hline 2012 & $3,635.50$ & $5,007.70$ & 137.74 \\
\hline 2013 & $4,468.90$ & $4,805.6$ & 133.53 \\
\hline 2014 & $4,086.10$ & $4,714.6$ & 115.89 \\
\hline 2015 & $4,572.20$ & $3,741.8$ & 81.84 \\
\hline 2016 & $4,200.20$ & $3,307.5$ & 78.75 \\
\hline 2017 & $4,889.70$ & $4,027.94$ & 82.38 \\
\hline 2018 & $6,747.00$ & $5,320.52$ & 78.86 \\
\hline Mean & & & $\mathbf{1 0 4 . 5 2}$ \\
\hline
\end{tabular}

Source: FIRS Publications, 2020

From Tables 1 and 2, the mean actual/target ratio is $116.11 \%$ for pre-SAS period and $104.52 \%$ for
post-SAS period. This shows actual performance was above the target in the period before and after 
implementation of SAS. However, the ratio dropped by $11.59 \%(116.11 \%$ - $104.52 \%)$ compared to pre-SAS implementation period. For four consecutive years 2015 to 2018 during the post-SAS period, the FIRS never achieved its tax collection target. In the pre-SAS period, the year 2006 saw the lowest ratio of $61 \%$.
The data relating to tax collection, GDP and tax/GDP ratio before and after implementation of SAS are presented in Tables 3 and 4 .

Table-3: Pre-SAS Tax Revenue, GDP and tax to GDP ratio (2003 to 2010)

\begin{tabular}{|l|l|l|l|}
\hline Year & Tax Revenue Nbillion & GDP Nbillion & Tax/GDP \% \\
\hline 2003 & 703.1 & $13,301.56$ & 5.27 \\
\hline 2004 & $1,194.80$ & $17,321.30$ & 6.90 \\
\hline 2005 & $1,741.80$ & $22,269.98$ & 7.82 \\
\hline 2006 & $1,866.20$ & $28,662.47$ & 6.51 \\
\hline 2007 & $1,846.90$ & $32,995.38$ & 5.60 \\
\hline 2008 & $2,972.20$ & $39,157.88$ & 7.59 \\
\hline 2009 & $2,197.60$ & $44,285.56$ & 4.96 \\
\hline 2010 & $2,839.30$ & $54,612.26$ & 5.20 \\
\hline Mean & \multicolumn{3}{|c|}{} \\
\hline
\end{tabular}

Source: FIRS/CBN Statistical Bulletin, 2020

Table-4: Post-SAS Tax Revenue, GDP* and tax to GDP ratio (2011 to 2018)

\begin{tabular}{|l|l|l|l|}
\hline Year & Tax Revenue Nbillion & GDPNbillion & Tax/GDP \% \\
\hline 2011 & $4,628.50$ & $62,980.40$ & 7.35 \\
\hline 2012 & $5,007.70$ & $71,713.94$ & 6.98 \\
\hline 2013 & $4,805.6$ & $80,092.56$ & 6.00 \\
\hline 2014 & $4,714.6$ & $89,043.62$ & 5.29 \\
\hline 2015 & $3,741.8$ & $94,144.96$ & 3.97 \\
\hline 2016 & $3,307.5$ & $101,489.49$ & 3.26 \\
\hline 2017 & $4,027.94$ & $113,711.63$ & 3.54 \\
\hline 2018 & $5,320.52$ & $127,736.83$ & 4.17 \\
\hline Mean & & & $\mathbf{5 . 0 7}$ \\
\hline
\end{tabular}

Source: FIRS/CBN Statistical Bulletin, 2020

*Current Basic Annual Prices

From Tables 3 and 4, the mean tax/GDP ratio is $6.23 \%$ for pre-SAS implementation but dropped to $5.07 \%$ post-SAS implementation period.

\section{Test of Hypotheses}

The hypotheses that were formulated are tested in this section.

$\mathrm{Ho}_{1}$ : There is no significant statistical difference in mean value of actual/target tax collection before and after the implementation of self-assessment in Nigeria

A paired sample t-test was done in order to find out whether the difference in mean between the pre- and post-SAS implementation actual/target tax collection was significant. The result is presented on Table 5.

Table-5: Paired Samples Statistics

\begin{tabular}{|l|l|l|l|l|c|}
\hline \multicolumn{2}{|c|}{} & Mean & N & Std. Deviation & Std. Error Mean \\
\hline Pair 1 & Pre-SAS-actual/target tax & 116.11 & 8 & 26.277 & 9.290 \\
\cline { 2 - 7 } & Post-SAS-actual/target tax & 104.51 & 8 & 26.493 & 9.367 \\
\hline
\end{tabular}

Source: SPSS Version 20 Output, (2020)

Results showed that the Post-SAS mean of 104.51, SD = 26.493; Pre-SAS mean of 116.11; SD = 26.277. These results suggest that the FIRS performance, in terms of actual/budgeted tax collection, was better before the introduction of SAS, but declined during the period SAS was implemented.

Table-6: Paired Samples Test- actual/target tax collection

\begin{tabular}{|c|c|c|c|c|c|c|c|c|c|}
\hline & \multicolumn{5}{|c|}{ Paired Differences } & \multirow[t]{3}{*}{$\mathrm{T}$} & \multirow[t]{3}{*}{$\mathrm{df}$} & Sig. (2-tailed) \\
\hline & & \multirow[t]{2}{*}{ Mean } & \multirow[t]{2}{*}{$\begin{array}{l}\text { Std. } \\
\text { Deviation }\end{array}$} & \multirow{2}{*}{$\begin{array}{l}\text { Std. } \\
\text { Error } \\
\text { Mean }\end{array}$} & \multicolumn{2}{|c|}{$\begin{array}{l}\text { 95\% Confidence Interval } \\
\text { of the Difference }\end{array}$} & & & \\
\hline & & & & & Lower & Upper & & & \\
\hline Pair 1 & $\begin{array}{l}\text { Pre-SAS } \\
\text { Post-SAS }\end{array}$ & 11.598 & 32.605 & 11.528 & 15.661 & 38.856 & 1.006 & 7 & .348 \\
\hline
\end{tabular}


Table-7 is paired sample t-test to find out whether the difference in mean between the pre- and post-SAS implementation actual/target tax collection ratio was significant. It was noted in Table 6 that there was a decline in mean of actual/budgeted tax collection after SAS was introduced as the preferred tax system in Nigeria beginning in 2011. The paired sample t-test result found this difference to be statistically insignificant, $\mathrm{t}(7)=1.06<1.895$ and the $\mathrm{p}$-value was $0.348>0.05$. This suggests that the introduction of SAS has not significantly affected the FIRS's actual/budgeted tax collection. The difference in mean may be due to factors outside of the implementation of SAS. The null hypotheses, that there is no significant statistical difference in mean value of actual/budgeted tax collection before and after the implementation of self-assessment in Nigeria, is therefore, accepted.

Hypothesis 2: There is no significant statistical difference in mean value of tax revenue/ GDP before and after the implementation of self-assessment in Nigeria.

A paired sample t-test was carried out to determine whether there is statistically significant difference in mean value of tax/GDP ratio before and after the implementation of SAS in Nigeria. The results of the analysis are presented in Tables 8 and 9.

Table-7: Paired Samples Statistics

\begin{tabular}{|l|l|l|l|l|l|}
\hline \multicolumn{2}{|c|}{} & Mean & N & Std. Deviation & Std. Error Mean \\
\hline \multirow{2}{*}{ Pair 1 } & Pre-SAS Tax/GDP & 6.23 & 8 & 1.127 & .399 \\
\cline { 2 - 6 } & Post-SAS Tax/GDP & 5.07 & 8 & 1.576 & .557 \\
\hline
\end{tabular}

Source: SPSS Version 20 Output, (2020)

From Table- 8 a difference in mean between the Pre-SAS tax/GDP and Post-SAS tax/GDP is observed. Pre-SAS mean $=6.23$; post-SAS mean $=$ 5.07. There is actually a decline in mean value.
Whether the difference in mean is statistically significant would be determined by the paired sample t-test results.

Table-8: Paired Samples Test

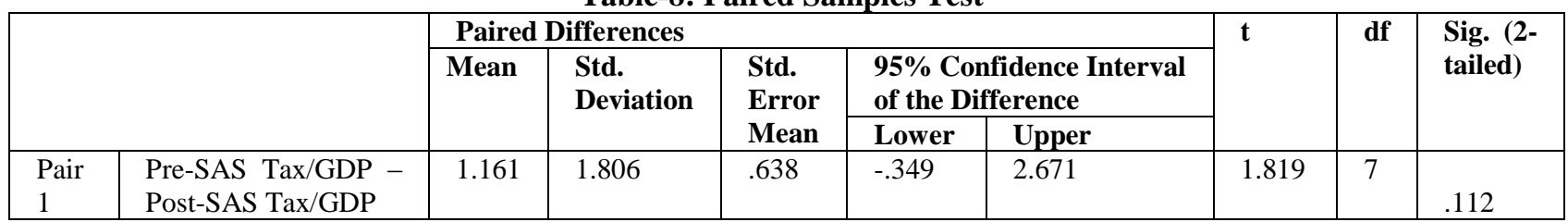

Source: SPSS Version 20 Output, (2020)

The paired sample t-test result found this difference to be statistically insignificant, $\mathrm{t}(7)=1.819$ $<1.895$ and the $\mathrm{p}$-value was $0.112>0.05$. This suggests that the introduction of SAS has not significantly affected the tax/GDP ratio. The difference in mean may be due to factors outside of the implementation of SAS. The null hypotheses, that there is no significant statistical difference in mean value of tax/GDP ratio before and after the implementation of self-assessment in Nigeria, is therefore, accepted.

\section{DISCUSSION OF FINDINGS}

Analyses of data obtained for this study revealed that the mean actual/target ratio in the pre-SAS period 2008 to 2010 was actually higher, and better than the post-SAS era of 2011 to 2018. The mean pre-SAS tax/GDP ratio was also higher and better than the same indicator in the post-SAS era. From the data obtained tax/GDP ratio showed a steady decline from $7.35 \%$ in 2011 to $3.26 \%$ in 2016 , and the tax authority failed to meet revenue targets in 2015 to 2018. Apparently, the results suggest that the major changes made to increase efficiency of tax collection through the self-assessment system have failed to yield the desired outcome. This is contrary to results obtained by researchers such as Loo in Malaysia [21], in Indonesia [19], in Maylasia and [12] in Zimbabwe; among others.

Further analyses using paired sample t-test, however showed that the difference in mean values between the pre-SAS and post-SAS actual/target tax revenue and tax/GDP ratio, though negative were statistically insignificant. This conclusion appears to collaborate the result of a study conducted in Nigeria by [13] which indicate a "slightly higher" but statistically insignificant post self-assessment system tax compliance.

\section{SUMMARY, CONCLUSION AND RECOMMENDATIONS}

This study was undertaken to assess the impact of self-assessment system of tax collection on tax revenue in Nigeria. A major objective of the system stated in the Self-Assessment Regulation, 2011 is to support efficient tax administration system in Nigeria. The study used two variables to measure the efficiency of the system, namely actual/budgeted tax collection ratio and tax/GDP ratio. Data on GDP for the relevant years were obtained from CBN Statistical bulletin and data on tax revenue and targets were obtained from 
Federal Inland Revenue Service. Using paired sample ttest for data analysis, the study found a negative but statistically insignificant impact of the self-assessment system on tax/GDP ratio and actual/target and tax/GDP ratio. This result contradicts well documented efficiency of SAS in several empirical studies in other countries. This study, therefore, recommends a further review of the Self-Assessment Regulation to include a responsibility on the part of tax authorities to enlighten taxpayers on the need to improve compliance behaviour.

\section{REFERENCES}

1. Appah E, Ogbonna GN. Self-assessment scheme and revenue in Nigeria. 2014. https://www.semanticscholar.org/paper/Self-

Assessment-Scheme-and-Revenue-Generation-inAppah-

Ogbonna/27f25c4626f10db9ecbecc0dec833f84f80 17ab6. Retrieved on April 17, 2020

2. Anjaneyulu A. Tax to gdp ratio. 2020. https://cleartax.in/g/terms/tax-to-gdp-ratio.

Retrieved on May 19, 2020

3. Eluro DC. Determinants of tax compliance under self-assessment: evidence from Delta North senatorial zone. Research Journal of Finance and Accounting. 2018; 9(7):95-108.

4. Eriksen K, Fallan L. Tax knowledge and attitudes toward taxation: a report on a quasi-experiment. Elsevier Journal of Economic Psychology. 1996; 17:387-402

5. Eseneyen JM. Taxpayers' knowledge and attitude towards tax compliance under self-assessment in Nigeria, PhD Thesis of University of Uyo, 2019; 132.

6. FGN (Federal Government of Nigeria). National Tax Policy. Federal Ministry of Finance Publications, Government Press, Abuja. 2012; 56.

7. Kagan J. What is tax to GDP Ratio. 2020. https://www.investopedia.com/terms/t/tax-to-gdpratio.asp

8. Kelly H. Attribution theory, http://albana 19 . Blogspot.com/2014/01 attribution theory-haroldkelly-1973. 1973. html, (Retrieved 12th May, 2020)

9. Kolade T, Ajogbor P. Nigeria's Unchanging Tax to GDP Ratio: An Instructive Appraisal. 2019. https://www.mondaq.com/Nigeria/Tax/848314/Ni geria39s-Unchanging-Tax-To-GDP-Ratio-AnInstructive-Appraisal. Retrieved on May 18, 2020

10. Komolafe B, Akpan U. Nigeria's oilrevenue risesby $129 \%$ to N9.4 trillionin 2018. 2019. https://allafrica.com/stories/201902050244.html. Retrieved on March 8, 2020

11. Loo EC. The influence of the introduction on self- assessment on compliance behaviour of individual taxpayers in Malaysia. PhD Thesis. University of Sydney. 2006; 224.

12. Maseko N. The impact of personal tax knowledge and compliance costs on tax compliance behaviour of SMEs in Zimbabwe. Elite Research Journal of Accounting and Business Management. 2014; 2(4):26-37.

13. Masud A, Akali MY, Aliyu A. Tax Complexity and Tax Compliance in Pre and Post SelfAssessment System Implementation in Nigeria. 2015.

https://www.researchgate.net/publication/2979179

91_Tax_Complexity_and_Tax_Compliance_in_Pr e_and_Post_Selfassessment_System_Implementati on_in_Nigeria. Retrieved on May 18, 2020

14. McKerchar M. The impact of income tax complexity on practitioners in Australia. Australian Tax Forum. 2007; 20(4):529554.

15. Nurlis IK. The effect of taxpayer awareness, knowledge, tax penalties and tax authorities' services on tax compliance: Survey on the individual taxpayer at Jabodetabek and Bandung. Research Journal of Finance and Accounting. 2015; 6(2): 25-41.

16. Odusola A. Tax policy reforms in Nigeria. 2016. https://www.researchgate.net/publication/2354768 5_Tax_Policy_Reforms_in_Nigeria. Retrieved on May 19, 2020.

17. Okello A. Managing Income Tax Assessment through Self-Assessment, IMF Working Paper, 2014; WP/14/41, 37.

18. Olalekan F. FIRS' Nami doubtful of meeting Buhari's revenue target, runs to Lagos for help. 2020.

https://nairametrics.com/2020/02/19/firs-namidoubtful-of-meeting-buharis-revenue-target-runsto-lagos-for-help/. Retrieved on April 29, 2020.

19. Palill MR, Mustapha AF. Factors affecting tax compliance behavior in self-assessment system. African journal of business management. 2011; 5(5):33-45.

20. Ramprasad AS. What does a lower tax to GDP ratio indicate? 2016. https://www.quora.com/What-does-a-lower-tax-toGDP-ratio-indicate.

21. Saad N. Tax Knowledge, Tax Complexity and Tax Compliance: Taxpayers' View. 2nd World Conference on Business, Economics and Management (WCBEM 2013). 2013.

22. Wood C, William M, Doyle J. Economic literacy among corporate employees. The Journal of Economic Education. 2002; 33(3):195-205. Retrieved from www.jstor.org. April 18, 2020. 